\title{
Ebb and Flow: Breath-Writing from Ancient Rhetoric to Jack Kerouac and Allen Ginsberg
}

Stefanie Heine

\begin{abstract}
Following the path of Charles Olson, Jack Kerouac and Allen Ginsberg negotiate breath as a compositional principle for a new particularly American literature. Such a poetics of breathing turns out to be a revival of classical thought. For ancient rhetoricians, especially Aristotle, Cicero and Quintilian, the breath-pause is constitutive for structuring speech. Already in the ancient approaches, a dilemma emerges: breathing is supposed to cut speech into well-measured units while physical respiration tends to be irregular. Even though the Beat poets seem to elude this problem in their attempt to adapt composition to the writer's individual rhythms, breath, as they theorise it, is a point where bodily processes and cultural techniques intersect. The natural, organic body as Kerouac and Ginsberg celebrate it invokes a cultural memory, and thus, the idea of a purely embodied writing is upset.
\end{abstract}

Keywords Breath - Embodied poetics • Jack Kerouac • Allen Ginsberg • Ancient rhetoric

Verse now, 1950, if it is to go ahead, if it is to be of essential use, must, I take it, catch up and put into itself certain laws and possibilities of the breath, of the breathing of the man who writes as well as of his listenings. ${ }^{1}$

(C) The Author(s) 2019

A. Rose et al., Reading Breath in Literature, Palgrave Studies in Literature, Science and Medicine, https://doi.org/10.1007/978-3-319-99948-7_5 
The opening claim of Charles Olson's influential essay "Projective Verse," already touched upon in the introduction of this book, responds to a set of questions that would occupy two circles of avant-garde writers in the 1950s and 1960s, the Black Mountain poets and the Beat movement: How can a new literature that radically breaks with tradition be inaugurated? What basis can it have, if not tradition? "The laws and possibilities of the breath," a recourse to "natural" bodily processes, promises freer expression and an emancipation of American poetry from old, formal conventions. Liberating language from the shackles of fossilised, dusty rules of metre and rhyme will vivify and renew it, while transferring the author's breathing rhythm to that of the words written will produce an organic, embodied literature that reconciles art and life. In his discussion of breath, Olson refers to the "revolution of the ear," pointing to a revival of orality in American poetry starting from Walt Whitman and extending to Ezra Pound and William Carlos Williams. His claims that "breath allows all the speech-force of language back in" and "speech is ... the secret of a poem's energy" 3 could be read as a call for spoken literature, for words carried by physical breath, which are more lively than those "which print bred."

For a number of writers of both the Beat and Black Mountain context, "speech-force" was not only to be realised in oral performances, but should also affect the words in the composition process, in which breath would function as a measure that is "arriv[ed] at ... organically." ${ }^{5}$ Olson, like Allen Ginsberg, ${ }^{6}$ establishes a simple compositional principle: break the line when you run out of breath:

And the line comes (I swear it) from the breath, from the breathing of the man who writes, at the moment that he writes, ... for only he, the man who writes, can declare, at every moment, the line its metric and its ending — where its breathing, shall come to, termination. ${ }^{7}$

Similarly, Jack Kerouac proposes that a dash shall indicate the moment between inhalation and exhalation, when breath is drawn, replacing the commas and colons that more commonly separate grammatical and semantic units. ${ }^{8}$ In these approaches, "preconceived metrical pattern[s]" are counteracted with more irregular, variable and individual structures derived from "a source deeper than the mind ... the breathing and the belly and the lungs." 


\section{Ancient Origins of the Breath-Stop}

What was advocated as a fresh principle for a new literature in the essays, writing manuals and oral comments of the Beat and Black Mountain writers was actually a tacit renascence of classical thought. In ancient rhetoric, the importance of breathing as a bodily prerequisite for oral delivery and as a structuring element of speech was stressed by Aristotle, Cicero and Quintilian. Breath had a pivotal role in the creation of prose rhythm, which the rhetoricians considered as more loosely measured than poetry. Prose should be structured in sequences, for example "periods," which Aristotle defines as "sentence[s] that [have] a beginning and an end in [themselves]." 10 In line with the compositional ideas of the Beat and Black Mountain writers, for the rhetoricians breathing marks the intervals between structural sequences. Aristotle mentions that a period should be delivered "in a breath ... taken as a whole" 11 and Cicero asserts that "there should be in speeches closes [of periods] where we may take breath." 12

The period in ancient rhetoric is a clearly defined unit: a segment that represents a thought with a beginning and an end. This idea is taken up by Ginsberg and Kerouac. Ginsberg claims that the "[b]reath-stop and the thought-division could be the same," 13 and Kerouac observes that a jazz musician blows "a phrase on his saxophone till he runs out of breath, and when he does, his sentence, his statement's been made ... . That's how I therefore separate my sentences, as breath separations of the mind." 14 With the assumption that a unit of breath coincides with a unit of thought or a completed statement, Kerouac and Ginsberg consciously or unconsciously follow the rhetoricians. ${ }^{15}$ What Kerouac and Ginsberg designate as a poetics of the body meets an old matter of controversy around the sound execution of artistic composition and sometimes unpredictable physical needs. The question arising for the ancient rhetoricians, Kerouac and Ginsberg, is: How does the necessity of drawing a breath while speaking undercut claims to a synchronicity of breathing and thinking? ${ }^{16}$

The reflections of the rhetoricians indicate that a seamless coincidence of sense and breath units cannot be taken for granted. ${ }^{17}$ In Quintilian's detailed account of how a speech should be delivered orally, it becomes obvious that an exact concurrence of breathing pause and the completion of a period are only an aspirational ideal. ${ }^{18}$ The rhetoricians generally argue that the completion of a period should determine the moment 
when a breath is drawn, and not the other way round. Cicero stresses that only the "unskilful and ignorant speaker ... measures out the periods of his speech, not with art, but with the power of his breath." ${ }^{19} \mathrm{He}$ argues that the breathing pause should be motivated by coherent segments of speech rather than the bodily need to inhale: "there should be in speeches closes [of periods] where we may take breath not when we are exhausted, ... but by the rhythm of language and thoughts." 20 Quintilian notes that the orators can train their breath through physical exercise in order to make it more amenable to the need to mark a period: "we ought to exercise it [the breath, or breathing], that it may hold out as long as possible."21

In this respect, Kerouac's and Ginsberg's position is diametrically opposite: the physical need to draw a breath shall determine the interval between thoughts and constitute the structural unit. To repeat, Ginsberg claims that the measure of the breath-stop is "arriv[ed] at ... organically" and rhythmical structures come from "a source deeper than the mind ... the breathing and the belly and the lungs." Kerouac stresses that he separates his phrases when he "draw[s] a breath"22 like the saxophonist does when "he runs out of breath." ${ }^{33}$ However, their commitment to what Cicero designates as rude oratory does not resolve the tension between the physical necessity to inhale and the breathing pause as a structuring principle of speech already present in antiquity. The units of thoughts and statements addressed by Kerouac and Ginsberg undermine their claim of a compositional principle solely generated from the body. In the reference to the coincidence of breathing and structural units, the "nature" of their compositional theories as a cultural inheritance becomes obvious; the unaddressed yet distinctly audible resonances with ancient rhetoric alone unsettle the idea of an art that comes to be in a fully organic manner. In the context of their writings, breath does not only refer to the body "of the man who writes," but also back to a rhetorike techne in which they are engaged. What is proposed as a means to approach a reconciliation of art and life in fact turns out to be a discursive vitalism pointing to an older discourse and cultural technique in which a seamless coincidence of body and artistic composition has already been challenged.

Against the background of this incongruity, this chapter traces the contradictions of Ginsberg's and Kerouac's notions of a vital, bodily breath-writing. In the comments about their writing process, neither Ginsberg nor Kerouac give a clear definition of what the proposed 
segments, the "mind-breaks" or "thought-divisions" in Ginsberg's case, and the "phrases," "sentences" or "statements" in Kerouac's case actually consist in. ${ }^{24}$ Whether the two writers actually did break up their lines or sentences when they had to inhale is impossible to verify in written documents. While one can check drafts and manuscripts for where linebreaks are made and where dashes or other pause markers are inserted, this textual geneticism does not demonstrate Kerouac's and Ginsberg's actual breathing patterns. ${ }^{25}$ Moreover, their poetics of breath rests on collapsing a fundamental difference between oral and written composition. What the ancient rhetoricians have in mind is a scenario of oral composition: the orator composes his sentences as he speaks. In contrast, Ginsberg and Kerouac primarily composed in writing: by hand or with a typewriter. When the writer "pronounces" the words in his head while writing, a need to inhale does not necessarily coincide with the moment where a breathing pause would have occurred if the same sentence were spoken. In fact, we may place many more words in the span of one breath if we pronounce them in our head than if we pronounce them orally. ${ }^{26}$ In contrast to oral composition, in writing, composition is not inevitably affected by the necessity to draw a breath: while writing, one can inhale without this effecting a pause in the sentence put on paper. When breath-measure is applied to written composition, its organic foundations disappear. Concerning Kerouac's and Ginsberg's texts, one observation is obvious: the pause markers almost always seamlessly coincide with grammatical units - so either the "laws ... of the breath" were ignored in the actual writing process, or they do not structure speech differently to standard grammatical units. Moreover, if a healthy body also "unconsciously" follows the control of the mind to such a degree that breathing adjusts itself to anticipated syntactic breaks, the "laws of the breath" may actually (and unintentionally) be the "laws of the mind" rather than "a source deeper than the mind." 27

The only documented cases where Ginsberg adopted an oral compositional technique are his so-called auto-poesy tapes. In a lecture, Ginsberg later explicates his recording compositions in terms of his theory of the mind- and breath-stop:

most machines have a "stop" and a "start" button ..., so if you're actually intending to do writing, one way is to use the automatic "control" button as the margin of your line ... . That is, you're talking into the machine, you don't have anything to say, so you click it off. Then, when something 
emerges, when you notice something $\ldots$ - click! Then, when you're transcribing on a page, ... which I've done a lot, from ' 65 to' 70 , with a Uher machine, you can use the "click" at the end of the tape line, the tape operation, as your breath stop. ... [I]t's the natural end of the line. ${ }^{28}$

An investigation of the tapes archived at Stanford University shows that what Ginsberg presents here is indeed a theory-a theory that does not match his compositional practice. Not only does he rarely use the stop and start buttons during composition, but the pauses in the recordings do not always coincide with the line-breaks in the printed poems. In most cases, it is unlikely that the pauses mark moments where Ginsberg ran out of breath; they rather indicate points where he ran out of thought: often, he only speaks two or three words, followed by very long intervals during which numerous breaths can be taken, often punctured by interjections like "ahem." Consequently, when Ginsberg designates the "natural" end of a line as "breath-stop" in retrospect, he uses the term as an image for the mind-break, or as a name for the line-break in the written text (note that in the lecture, he comes up with breath in the context of transcribing the spoken poem), which has little to do with his actual breathing during composition.

Following these observations, it has to be stressed that Kerouac's and Ginsberg's reflections of breathing and writing are poetological theories rather than descriptions of actual composition processes. While it is worth considering these in their own right, it is important to be aware of the ambivalent position bodily breath thereby comes to occupy: while it is celebrated as the natural source of a literary text's structure, its actual role in the writers' compositional practices seems to be marginal. Bearing this ambivalence in mind, I will elucidate the particularities of Kerouac's and Ginsberg's poetics of breathing, whose fixation on vitalism turns out to be grounded more in discourse than in physiology. The trajectories of their respective poetological endeavours become explicit when counterpointed against theories of rhetorical composition. Thus, I want to pair Ginsberg with Quintilian and Kerouac with Aristotle, focusing especially on the character and function of the caesura.

\section{Ginsberg and Quintilian}

Ginsberg claims that the so-called natural speech pauses, which he identifies with "breath-stops," "indicate mind-breaks." 29 The "[b]reath stop is where you stop the phrase to breathe again. Stop to think and 
breathe." 30 By claiming that "you're gonna stop and take a breath" when "you run out of thought and words,"31 he recalls Quintilian, who argues that the pause is the "point, where the mind takes a breath and recovers its energy." 32 For Quintilian, the breathing pause is the moment "when the rush of words comes to a halt" 33 and the mind is relieved from its work. The pause should provide a rest so that the orators can assemble their mental forces anew before the next compositional effort. When claiming that the mind takes a breath, Quintilian deploys a metaphor invoking the intake of vital breath. ${ }^{34} \mathrm{He}$ addresses the "rush of the words" the pause interrupts and thus recalls a common association tied to the metaphor of "taking a breath" in the sense of relaxing: slowing down, i.e. the pace of one's breathing rhythm. To do nothing except breathe seems to suggest that one does almost nothing: "taking a breath" is "pausing." The image of the mind taking a breath during the pause implicates that the mind stops doing what it usually does, namely thinking. By claiming that the mind takes a breath in the moment of the breathing pause, Quintilian rhetorically establishes a temporal coincidence of metaphorical breath and its literal, or, precisely speaking non-linguistic, bodily referent.

In his remarks on the breathing pause and writing, Ginsberg also tries to reconcile metaphorical and literal dimensions of breathing. In the sentence "when you talk and then after a while you run out of thought and words, ... then you're going to stop and take a breath and continue," Ginsberg synchronises the metaphor of "taking a breath" 35 with physical inhalation. Like Quintilian, he suggests that the breathing pause between uttered words (literally taking a breath) is a moment of rest and recovery (metaphorically taking a breath) — and that the mind needs to rest when the speaker runs "out of thought." Ginsberg also addresses the other implications of "taking a breath," discussed in Quintilian's use of the metaphor: inhaling vitalising air and doing almost nothing. $\mathrm{He}$ states that during the pause, the writer is "waiting for the next thought to articulate itself." 36 By noting "you're improvising and you're relying on the moment-to-moment inspiration," 37 Ginsberg suggests that physical inspiration, inhaling, coincides with inspiration in the classical sense: the generation of creative ideas. The metaphorical breath of life as a vitalising force is thus transferred to the domain of artistic work in process. Drawing on his preoccupation with Buddhist thought and meditation practices, Ginsberg considers it relevant that ideas are generated where nothing is written or thought. The "blank spots," or "gaps in between the thoughts," 38 Ginsberg addresses in this context overlap exactly with 
the point where he locates the breath-stop. Out of the "unborn awareness," 39 a space of pure potentiality that opens in the moment when we do nothing but breathe, new thoughts are generated. The conflation of the physiological process of breathing, that is, the so-called natural pause or breath-stop and the mind-break, with the emergence of new ideas, that is, inspiration, becomes most noticeable in his "Notes on Howl": "Ideally each line of Howl is a single breath unit ... -that's the Measure, one physical-mental inspiration of thought contained in the elastic of a breath. $" 40$

Even though Ginsberg encourages his readers to take both the metaphor of "taking a breath" and the notion of inspiration literally, his theory pushes physical respiration into the background. The claim that breath is a "source deeper than the mind" is made plausible in Ginsberg's comments on thought-generating "unborn awareness." However, reconciling breathing and inspiration in this way does not explain why the end of a thought should coincide with the need to draw a breath. The neat outline of "breath-stop $=$ mind-break=inspiration" is an attempt to bring the body into agreement with compositional techniques, traditional ideas about how creative works are generated and theories of thought processes. Such a carefully constructed model—clearly a work of a well-read mind-stands in conflict with the claim that the work of the respiratory organs, which proceeds according to its own mechanisms, is supposed to generate the rhythmical structures of the poem in process. The fact that breathing rhythms are influenced by accidental external circumstances and the respective bodily condition of the breather-which, quite surprisingly for a position that supposedly foregrounds the body, is never addressed by Ginsberg-counteracts the idea that "mind-breaks" should necessarily be "identical with natural speech pauses." 41 On the one hand, it is precisely the irregularity of breathing that makes it interesting for Ginsberg's polemic towards a new poetry: he stresses that, in contrast to the "automatic and mechanic," symmetrical and "even" measure of traditional metrical forms, poetry as he envisages it, "speech as breath from the body," is more variably structured. ${ }^{42}$ On the other hand, the irregularities of a human's breathing rhythm run counter to the smooth symmetry Ginsberg establishes in his compositional theory. Ginsberg considers the work of the mind as a process which is at the same time bodily and intellectual. ${ }^{43}$ His negotiations of breath and mind-breaks thus challenge a simple binary between a rational, intellectual mind and an irrational, animalistic body. However, the cost of this 
by all means productive questioning of a dualism that keeps haunting the Western world is an eradication of difference: Ginsberg seals the gap between mind and body that especially articulates itself when the body speaks, or to be precise, breathes. He claims that mind-breaks are the same as non-metaphorical breath-stops, that is, the pauses between inhalation and exhalation in the physical respiration process.

\section{Kerouac and Aristotle}

Kerouac first and foremost links breathing to the free mind-flow and uncensored expression:

PROCEDURE ... sketching language is undisturbed flow from the mind of personal secret idea-words, blowing (as per jazz musician) on subject of image.

SCOPING Not "selectivity" of expression but following free deviation (association) of mind into limitless blow-on-subject seas of thought, swimming in sea of English with no discipline other than rhythms of rhetorical exhalation and expostulated statement ... - Blow as deep as you wantwrite as deeply, fish as far down as you want. ${ }^{44}$

CENTER OF INTEREST ... blow! - now! - your way is your only way"good"—or "bad"—always honest ("ludicrous"), spontaneous, "confessional" interesting, because not "crafted." 45

The most obvious basis for the comparison of mind-flow and breath is a term Kerouac adopts from jazz music: "blowing." In jazz, "blowing" refers to improvisation. ${ }^{46}$ In the case of the improvised saxophone-solo Kerouac addresses in his Paris Review interview, such an improvisation is literally blown. With respect to the breath-carried sounds produced by the saxophonist and, by analogy, by the speaker who improvises literary texts, Kerouac's image has a physiological basis. However, the suggested continuity of the flow of the mind and breathing is as rhetorically constructed as Ginsberg's equation of breath-stop and mind-break. This analogy is informed by the idea that physical breathing happens unconsciously and thus escapes from those grammatical and syntactical rules that restrict the mind's free expression-prohibitions the conscious mind cannot ignore. Further, the flow of exhaled air lends itself to a comparison with the stream of consciousness. 
Kerouac extends the analogy between breath and a liberated mind to language: the free flow of the mind shall be mirrored in the free flow of language. Kerouac does not go so far as to propose a purely fluent, unsegmented speech or writing. His alternative is to replace the barriers of conventional punctuation mirroring grammatical units with a less restraining separator, namely breath.

No periods separating sentence-structures already arbitrarily riddled by false colons and timid usually needless commas-but the vigorous space dash separating rhetorical breathing (as jazz musician drawing breath between outblown phrases) - ${ }^{47}$

While the ancient rhetoricians make a considerable effort to reconcile the breathing pause and grammatical units in their arguments, Kerouac is eager to separate the two. In ancient rhetoric, the image of flowing water, which Kerouac invokes in the "flow" and the "seas" of language, is used in order to depict what is spoken between the pauses: Quintilian mentions "the unbroken flow of the voice ... being carried along down the stream of oratory" 48 and Cicero compares ongoing speech with "the rolling stream of a river." ${ }^{49}$ In both cases, the breathing pause is what brings that flow to a halt. Even though he takes the caesura into account, Kerouac's reservations against anything that disturbs the flow are apparent.

In the unpublished essay "History of the Theory of Breath as a Separator of Statements in Spontaneous Writing," Kerouac extends his comparison of breath-measure to jazz music: in a handwritten addition, the jazz musician is equated with both a runner and orator, and jazz is mentioned in the same breath with oratory and a hundred-yard dash. The imperative "write excitedly, swiftly" 50 became the foundation of the most prominent Beat and Kerouac-myth, ${ }^{51}$ culminating in the repeatedly invoked scene of Kerouac taping together sheets of paper to a long scroll in order to avoid interruptions before manically typing down $O n$ the Road in three weeks. ${ }^{52}$ In Kerouac's discussion of running, pausing and writing, we find a striking echo of Aristotle. Aristotle argues that, in contrast to a style segmented by periods, colons and commas, the loose or continuous style is "unpleasant, because it is endless, for all wish to have the end in sight." ${ }^{" 53} \mathrm{He}$ gives the following reason for the benefits of the pause: "runners, just when they have reached the goal, lose their breath and strength, whereas before, when the end is in sight, they show 
no signs of fatigue." 54 The advantage of the pause is that it prevents fatigue, the loss of breath, and that it impels the runner to go on. In his argument for pauses, Aristotle looks at them prospectively, as something that lies ahead. Such a prospective view opens a very attractive possibility for Kerouac: the break no longer blocks the flow, but generates an impetus to speed on. In a letter to his agent Sterling Lord, Kerouac stresses that the dashes indicating the breathing pause mark something impending: "Make this clear, that my prose is a series of rhythmic expostulations of speech visually separated for the convenience of the reader's eye by dashes, by vigorous definite dashes, which can be seen coming as you read." 55 Kerouac also highlights the importance of looking ahead during composition in "History of the Theory of Breath": analogous to the writer of spontaneous prose, the jazz musician has to keep track of breath when he moves from one chorus to the next in order to create a continuity between segments.

For Kerouac, the pause as such, the moment when according to Aristotle the runners "lose their breath and strength," represents the most delicate moment in his theory of writing. Whereas Ginsberg emphasises the meditative potentiality of the pause as a moment of calmness and rest, Kerouac is focused on the speed of the flowing words. ${ }^{56}$ The idea of resting in the sense of slackening poses a threat to his obsession with mastery and an intact, potent masculine body mirrored in a muscular, virile prose.$^{57}$ The aspired athletic speed of writing should demonstrate vigour. Kerouac claims that he wants to write "[1]ike Proust, but on the run, a Running Proust." 58 "I decided to do just like he did-but fast. ... Fast. Marcel Proust had asthma and was lying around writing and eating in bed. Once in a while he'd get up feebly, put on a coat and go down a bar in Paris." 59 Just like Proust, Kerouac wants to write a monumental cycle of novels covering his entire life-but he neither wants to spend as much time as Proust did on the Recherche, ${ }^{60}$ nor, most importantly, to fail in accomplishing the oeuvre. His comments show that in wishing to be a "running Proust," Kerouac also wanted to ensure that he didn't mimic Proust's frailty. What Kerouac aspires to is an athletic writing in contrast to an asthmatic one. ${ }^{61}$ The breath Kerouac wishes to incorporate in his writing is one of a healthy, well-trained, potent body. It is significant that, in his emphasis on speed, Kerouac conceals the fact that a strained body may be out of breath, or that speaking on the run could be controlled by strained breath. ${ }^{62} \mathrm{~A}$ breath that indicates signs of the body's slackening or weakens it, a writing structured by asthma attacks and apnoea would 
endanger Kerouac's poetological pursuits. In other words, Kerouac cannot envision breathlessness in his poetic theory. A physiological foundation of writing is only desirable if the body in question is intact and disciplined into athletic strength. Spontaneous writing as such is considered as a result of discipline, or, to follow Kerouac's own image, the runner's sprint provides an immediate demonstration of what rigorous training and hardening muscles give rise to.

... the critics have failed to realize that spontaneous writing of narrative prose is infinitely more difficult than careful slow painstaking writing with opportunities to revise-Because spontaneous writing is an ordeal requiring immediate discipline-They seem to think there's no discipline involved-They don't know how horrible it is to learn immediate and swift discipline and draw your breath in pain as you do so. ${ }^{63}$

Spontaneous prose is described as the empowering accomplishment of hard work. The aching breath recalling Shakespeare's Hamlet ${ }^{64}$ results from the exertion of a well-trained body and stands in contrast to the painful asthmatic breath exhausting a body subject to illness. The reference to Proust's asthma and his debilitated physical condition shows Kerouac's longing for mastery over his body and writing alike: the healthy and strong body is a body under command. ${ }^{65}$ The athlete's control over his muscles creates the illusion that he is liberated from the more random works of the body that may affect a person (i.e. illness). The imperatives of a "defective" body have no place in Kerouac's theory of writing.

Consequently, Kerouac invests the breathing pauses with implications forbidding any possibility that they may be a symptom of the fatigued body. In this respect, it is significant how he describes the graphical sign that should mark the breathing pause and its function:

No periods separating sentence-structures already arbitrarily riddled by false colons and timid usually needless commas-but the vigorous space dash separating rhetorical breathing. ${ }^{66}$

... a sentence which after all is a rhetorical expostulation based on breathing and has to end, and I make it end with a vigorous release sign, i.e., the dash -67

By repeatedly describing the dash as "vigorous" (in contrast to the "timid" commas), Kerouac projects the strength of the runner into the 
pause, the moment when his body is in danger of collapsing and his muscles are bound to go limp. The aim of associating the pause with virility motivates the choice of the dash as the sign marking it on a semantic and graphical level: "dash" designates the punctuation mark Kerouac uses, but also the runner's sprint. Through the "dash," the pause develops a sense of speeding on. In Kerouac's handwritten manuscripts, the dashes also evoke an impression of speed graphically: often, the lines look as if they were dashed off energetically. Visually, the dash-in this case especially the printed one-establishes a proximity between words it separates: it links them by a vertical line almost touching their respective ends and beginnings, so that the eye is invited to follow this connection. Whereas a blank space between words encourages the eye to pause, the dash rather incites the eye to sprint between words. Moreover, in contrast to the bent commas and colons, the erect straight line of dash, which is also bigger in size, has a phallic quality. When his editor at the Grove Press, Don Allen, replaced dashes by full stops and added commas in the manuscript of The Subterraneans, Kerouac complained about this "horrible castration job." "He has broken down the organic strength of the manuscript and it is no longer THE SUBTERRANEANS by Jack K, but some feeble something by Don Allen." 68

Such a castration anxiety also explains why Kerouac mingles images of breath and sex in the "Essentials":

... write outwards swimming in sea of language to peripheral release and exhaustion-69

... write excitedly, swiftly, with writing-or-typing-cramps, in accordance (as from center to periphery) with laws of orgasm .... Come from within, out - to relaxed and said. ${ }^{70}$

"[E]xhaustion," which in terms of respiration represents a threati.e. Proust's asthmatic feebleness and Aristotle's drained runner who has lost his "breath and strength" - is redirected to the domain of sexual climax: Kerouac links the "relaxed" moment of the pause to an explosive "release" of male (creative) potency. Kerouac repeatedly writes that the dashes "release" the sentence. Beside the sexual connotations evoked in the "Essentials," "release" also designates "liberation," the "action of freeing, or the fact of being freed." Moreover, in jazz music, "release" designates a "passage of music that serves as a bridge between repetitions 
of a main melody."71 By choosing the word "release" in order to describe the function of the dash, Kerouac is able to connect all the qualities he wants to project into the breathing pause in order not to make it appear as slackening or escaping mastery: virility, liberation and a sense of continuity pointing forward to the point after the critical moment of the pause. The word also contains Kerouac's most eager wish: to make his writing available to the public, to release his written products, to get published and be honoured as America's healthy Proust. Kerouac's comments on his writing processes and methods, above all the "Essentials," were most important elements in his attempt to create a public image of himself as a writer. The potent, vigorously breathing body of the authoritative and controlling author Kerouac promotes is produced by his own words. Kerouac's literary texts are constructed in a way that evokes the impression of spontaneous, bodily, athletic writing executed by a vigorous author. The comments on the writing process and methods are designed to verify and confirm - and not least co-create- the effect produced in the literary texts. ${ }^{72}$

The texts by the ancient rhetoricians, Ginsberg and Kerouac, all imagine the writing or speaking body. In their discussions of the role of breath in writing, especially concerning the breathing pause, both Kerouac and Ginsberg follow in the footsteps of the rhetoricians. Whereas their poetological reflections start from the same premises, they ultimately diverge. Ginsberg's negotiation of the breathing pause amounts to a meditatively charged stasis, he emphasises the role of quiescent contemplation. Contrarily, Kerouac's poetics of breathing culminates in a promotion of flow, fast movement and virile athleticism.

\section{Notes}

1. Olson $(1966,15)$.

2. Ibid., 15 .

3. Ibid., 20.

4. Ibid., 15. Even though Olson stresses orality in "Projective Verse," it is not his only concern, or even a primary one. As Raphael Allison notes in his book Bodies on the Line: Performance and the Sixties Poetry Reading, "competing with Olson's emphasis on the breath, graphic text itself was to him of equal value" (68). Prescient to the authors to be discussed in more detail in this article and their relation to orality, it has to be noted that Jack Kerouac did refer to spoken language and the tongue in his 
comments on the new literature (e.g. in the unpublished essay "History of the Theory of Breath as a Separator of Statements in Spontaneous Writing") and did give public readings, but his overall focus has always been on writing and the written text. Allen Ginsberg's focus on the spoken word is much stronger: he repeatedly stresses its importance in his interviews (e.g. 2001, 81, 158, 272), and-as a grandfather of contemporary poetry slams - presenting his poetry orally to a live audience was a priority in his literary endeavours. The legendary reading of "Howl" at the Six Gallery is only one example.

5. Ginsberg $(2001,19)$.

6. "Ideally each line of Howl is a single breath unit. ... My breath is longthat's the measure, one physical-mental inspiration of thought contained in the elastic of a breath" (Ginsberg 1999, 416). "So you arrange the verse line on the page according to where you have your breath stop, and the number of words within one breath, whether it's long or short, as this long breath has just become" (Ginsberg 1997, 23).

7. Olson $(1966,19)$.

8. For example, Kerouac $(1992,57)$ and $\operatorname{Kerouac}(1999,15)$.

9. Ginsberg $(2001,19)$.

10. Aristotle $(1926,389)$.

11. Ibid.

12. Cicero $(1990,506)$. I take this short summary of the role of breath in ancient rhetoric from my article "animi velut respirant. Rhythm and Breathing Pauses in Ancient Rhetoric, Virginia Woolf and Robert Musil."

13. Ginsberg $(2001,359)$.

14. Kerouac (1968).

15. Neither Ginsberg nor Kerouac explicitly refers to ancient rhetoric. It is also unclear whether they read the rhetoricians' discussions of breath or may have been familiar with their ideas through secondary sources.

16. Regarding the empirical perspective on this matter, a study conducted at Northeastern University by François Grosjean and Maryann Collins from 1979 approaching the question "What is the relationship between linguistic structure and breathing?" (100) concludes that breathing pauses "occur mainly at major constituent breaks" (110). "[T]he need to breathe (at least at slow and normal rates) is not in control of pausing but ... on the contrary, breathing adjusts itself to pause patterns" (109). Only when the participants of the study were asked to speak very fast, their breathing pauses did not coincide with syntactic breaks: at faster rates "the physiological need to breathe forces the speaker to stop in order to inhale," disregarding syntactic units (112). It has to be mentioned that the study is based on the speaking of healthy participants who were asked to read a text in which punctuation marks indicated where 
the syntactic units are. Along with the fact that it is a quite old study, the results cannot be transferred seamlessly to the scenario of oral composition the rhetoricians and Beat and Black Mountain writers have in mind. However, it is revealing that breathing pauses and syntactic units seem to co-occur smoothly, but only as long as the body is under control, and that the physiological need to inhale tends to interrupt the syntax once the circumstances of the bodily condition for some reason changes.

17. Cicero attempts to conciliate the physical need to inhale and making a pause at the completion of a period by means of a quite constructed argument that beauty in artificial works is in agreement with natural utility $(1875,244)$.

18. Quintilian (1856, 352-353). Also in the passages on composition, there are uncertainties about the moment when a breath is required because a thought is completed at the moment when the orator should actually take a breath: "Who, for example can doubt that there is but one thought in the following passage and that it should be pronounced without a halt of breath? Still, the groups formed by the first two words, the next three, and then again by the next two and three, have each their own special rhythm and cause a slight check in our breathing" (Quintilian 1943, $545)$.

19. Cicero $(1875,243)$.

20. Cicero $(1990,506)$. The editor's comment to this passage shows that the rhetoricians' attempts to reconcile the completion of the period with the need to inhale leads to inconsistencies: "There is no real, though an apparent inconsistency: the periods must furnish opportunity for taking breath, but must not be determined solely by the need for this" (Cicero 1990, 506).

21. Quintilian $(1856,357)$. This overview of the breathing pause in ancient rhetoric is taken from my article "animi velut respirant. Rhythm and Breathing Pauses in Ancient Rhetoric, Virginia Woolf and Robert Musil.”

22. Kerouac $(1999,15)$.

23. Kerouac (1968), not paginated.

24. Even though the examples Ginsberg uses as illustrations in numerous interviews and line-breaks or sentence segmentations in Ginsberg's and Kerouac's literary texts give some indication of these units, a precise explication is still lacking.

25. Investigating the breath-stops in their oral deliveries, in contrast, is possible in the cases where recordings were made. In Ginsberg's recordings of Howl, for example, one can observe that the moments when he inhales and pauses do not always coincide with the line breaks. Even though Ginsberg stresses that he imitates the compositional process in his readings $(2001,126)$, the readings as such do not constitute valid data for 
an investigation of the composition process. The only thing one might infer from Ginsberg's Howl readings is that the moments when he has to inhale before the line ends show that his breath may not be as long as he claims in the Notes for Howl-even though he himself addresses this fact and attributes it to his exhaustion at the moment when he was reading (2001, 416).

26. This may explain Ginsberg's long lines in Howl, which he cannot pronounce in one breath orally (see 25 ).

27. See 16.

28. Ginsberg (1974).

29. Ginsberg $(2001,126)$.

30. Ibid., 108.

31. Ibid., 359.

32. Quintilian $(1943,543)$.

33. Ibid., 543 .

34. The Latin use of "respire," the verb used by Quintilian, already included the figurative meaning of breathing as resting: "to fetch one's breath again, to recover breath; to recover, revine, be relieved or refreshed after any thing difficult (as labor, care, etc.)" (Lewis and Short 1879).

35. In the Oxford English Dictionary, "to take breath" is considered to be a figurative use of the "[p]ower of breathing, free or easy breathing": "to breathe freely, to recover free breathing, as by pausing after exertion" (OED online).

36. Ginsberg (2001, 126).

37. Ibid., 411 .

38. Ibid., 365 .

39. Ibid.

40. Ginsberg $(1999,416)$.

41. Ginsberg $(2001,126)$. In the Q\&A session of lecture given in 1974, Ginsberg puts this claim into perspective and admits that his conceptions of mind units and breath units are not fully fleshed out. A student asked how Ginsberg uses his breath when he writes in a notebook: "do you read it out loud as you're writing it down?" In reply, Ginsberg mentions "It's an interesting thing whether it's breath or it's mind unit. I never figured that out" (Ginsberg 1974).

42. Ginsberg (2001, 107).

43. Ibid., 145 .

44. Kerouac $(1992,57)$, my emphasis.

45 . Ibid., 58 , italics in the original.

46. Witmer (2003).

47. Kerouac $(1992,57)$.

48. Quintilian (1943, 541). 
49. Cicero $(1875,247)$.

50. Kerouac $(1992,58)$.

51. Kerouac himself spent considerable efforts to create and maintain that myth, which for him goes hand in hand with having found his own style and "voice," most prominently expressed in the "Essentials." Significantly, the "Essentials" constitute an instruction to imitate, circulate and popularize the style Kerouac discovered for himself.

52. It has long been known that this is not an accurate description of how On the Road came to be and that Kerouac spent years taking notes and designing drafts for the novel (cf., for example Brinkley 2004, xxv).

53. Aristotle (1926, 387).

54. Ibid.

55. $\operatorname{Kerouac}(1999,11)$.

56. Even though Ginsberg occasionally also refers to speed, for example by referring to the next line to be written or read as "next spurt" (2001, 125 ), this is never at the centre of his reflections-he rather seems to be echoing Kerouac's ideas of “athletic speech" (Ginsberg 2001, 114) in these instances.

57. Kerouac stresses these characteristics on a small undated scrap of paper containing a list of desirable prose attributes.

58. Kerouac $(1995,515)$.

59. Kerouac $(2005,192)$.

60. Kerouac $(1995,515)$.

61. See Benjamin (1968).

62. See 16.

63. Kerouac $(1999,325)$.

64. "Draw your breath in pain" is, of course, an implicit quote. Kerouac was well aware of Hamlet's last words: he quotes "Absent thee from felicity awhile," the line preceding "And in this harsh world draw thy breath in pain," in a letter to Ginsberg written in 1947 (1995, 122). Moreover, in a letter to Neal Cassady in 1950, Kerouac makes an explicit reference to Hamlet, precisely when he "discovers" the strenuousness of writing spontaneously in one's own voice: “My important recent discovery and revelation is that the voice is all. Can you tell me Shakespeare's voice per se?-Who speaks when Hamlet speaks? HAMLET, not Will Shakespeare .... You, man, must write exactly as everything rushes in your head, and AT ONCE. The pain of writing is just that" $(1995,233)$. It is important to note that these earliest thoughts on spontaneous prose, in which breath is not explicitly mentioned, are inspired by Hamlet's last sigh.

65. In Proust's Recherche, a notion of mastery is not absent. To the contrary, the narrator uses his illness as a means to exert control over the characters he interacts with. In particular, in The Captive, the house he cannot leave 
due to his physical condition becomes a setting where Marcel can subject his lover Albertine to his supervision and bend her to his will as well as a stage for the dramas he directs. The space he is limited to because of his feeble physical condition is totally under Marcel's control, precisely because it is secluded from the contingencies of the outside world. In Le Souffle coupé. Respirer et écrire, François-Bernard Michel claims that asthma implies a closure of what is supposed to be open: the asthmatic closes his bronchia and thus conserves his air, he refuses to exhale (194). The intentionality insinuated in Michel's formulation is problematic, but it gets to the heart of Marcel's attempt of creating an enclosed space sealed from exposure to the outside. Thus, Proust's asthma represents a flip side to Kerouac's poetics of breathing. Not only are the two models of literary breathers similarly subject to mystification: the aesthetic idealisation of the fin de siècle decadent in Proust's case, the phallocentric, virile daredevil who lives fast and dies young in Kerouac's case. In contrast to the asthmatic, Kerouac's athletic writing embraces exhalation: "blowing" is the central respirational movement for Kerouac, and it has to be noted that in contrast, he is deeply suspicious of inhalation, of everything that enters the body from without and is not his own. Through his focus on exhalation, Kerouac stages an extension of the self to the outside world and is equally paranoid of a possible interference of the outside with the self as Proust is. The analogy of his writing and sprinting supports this: as an anaerobic exercise, the sprint relies on energy resources stored in the body-it allows a momentary fantasy of not being dependent on an oxygen supply from without.

66. Kerouac $(1992,57)$, my emphasis.

67. Kerouac $(1995,324)$, my emphasis.

68. $\operatorname{Kerouac}(1995,11)$.

69. $\operatorname{Kerouac}(1992,58)$.

70. Ibid.

71. OED online, my emphasis.

72. For a more detailed analysis of how the "Essentials of Spontaneous Prose" themselves represent a deliberate attempt to create an effect of spontaneity that first had to be carefully prepared, see my article "First Thought, Best Thought. Improvisation bei Jack Kerouac und Allen Ginsberg.” A look at Kerouac's manuscripts and drafts shows that the methods and techniques he proposes in his writing manuals and comments have never been consequently applied in his actual writing processes. I investigated a large bulk of materials at the Berg Collection of English and American Literature, among them drafts for The Subterraneans, On the Road and Visions of Gerard. A detailed discussion of these findings, however, exceeds the scope of this paper. Generally, it is worth noting that Kerouac 
made extensive use of "timid commas" and hardly used the dashes in a consequential manner (to replace commas, colons or full stops); most of the times, one can find a mixture of dashes, commas and full stops. I want to give only one example that demonstrates how Kerouac retrospectively_and against his imperative “no revisions" (1992, 57)—aligned his texts to his own writing instructions: in order to highlight that he replaces full stops by dashes, he consequently changes lowercased words succeeding a dash into capitalized ones in the setting copy of Visions of Gerard.

\section{References}

Allison, Raphael. 2014. Bodies on the Line: Performance and the Sixties Poetry Reading. Iowa, IA: University of Iowa Press.

Aristotle. 1926. The "Art" of Rhetoric, ed. and trans. John Henry Freese. London: William Heinemann.

Benjamin, Walter. 1968. The Image of Proust. In Illuminations, trans. Harry Zohn, intro. Hannah Arendt, 201-215. New York: Schocken Books.

"breath." OED Online. Oxford: Oxford University Press. www.oed.com. Accessed 13 Mar 2018.

Brinkley, Douglas (ed.). 2004. Windblown World: The Journals of Jack Kerouac 1947-1954. New York: Viking Penguin.

Cicero. 1875. Oratory and Orators, ed. and trans. J.S. Watson. New York: Harper \& Brothers.

Cicero. 1990. de Oratore libri tres, ed. August S. Wilkins. Hildesheim: Georg Olms Verlag.

Ginsberg, Allen. 1974. Spiritual Poetics II. Lecture at the Naropa University. https://archive.org/details/Allen_Ginsberg_class_Spiritual_Poetics_part_2_ July_1974_74P002. Accessed 12 Mar 2018.

Ginsberg, Allen. 1997. Allen Ginsberg: An Interview by Gary Pacernick. The American Poetry Review 26 (4): 23-27.

Ginsberg, Allen. 1999. Notes for Howl and Other Poems. In The New American Poetry 1945-1960, ed. Donald M. Allen, 414-420. Berkeley: University of California Press.

Ginsberg, Allen. 2001. Spontaneous Mind: Selected Interviews 1958-1996, ed. David Carter. New York: HarperCollins.

Grosjean, François, and Maryann Collins. 1979. Breathing, Pausing and Reading. Phonetica 36: 98-114.

Heine, Stefanie. 2014. First Thought, Best Thought. Improvisation bei Jack Kerouac und Allen Ginsberg. In Improvisation und Invention. Momente, Modelle, Medien, ed. Sandro Zanetti, 245-259. Zürich: Diaphanes. 
Heine, Stefanie. 2017. animi velut respirant. Rhythm and Breathing Pauses in Ancient Rhetoric, Virginia Woolf and Robert Musil. Comparative Literature 69 (4): 355-369.

Kerouac, Jack. 1968. The Art of Fiction No. 41. The Paris Review. www.theparisreview.org/interviews /4260/the-art-of-fiction-no-4l-jack-kerouac. Accessed 12 Mar 2018.

Kerouac, Jack. 1992. Essentials of Spontaneous Prose. In The Portable Beat Reader, ed. Ann Charters, 57-58. New York: Viking.

Kerouac, Jack. 1995. Selected Letters, 1940-1956, ed. Ann Charters. New York: Viking Penguin.

Kerouac, Jack. 1999. Selected Letters, 1957-1969, ed. Ann Charters. New York: Viking Penguin.

Kerouac, Jack. 2005. Dialogues in Great Books. In Empty Phantoms. Interviews and Encounters with Jack Kerouac, ed. Paul Maher, 184-202. New York: Thunder's Mouth Press.

Michel, François-Bernard. 1984. Le Souffle coupé: Respirer et écrire. Paris: Gallimard.

Olson, Charles. 1966. Projective Verse. In Selected Writings, ed. Robert Creeley, 15-26. New York: New Directions.

Quintilian. 1856. Quintilian's Institutes of Oratory: Or, Education of an Orator in Twelve Books, vol. II, trans. John Selby Watson. London: Bohn's Classical Library.

Quintilian. 1943. Institutio Oratia, trans. H.E. Butler. Cambridge: Harvard University Press.

"release." OED Online. Oxford: Oxford University Press. www.oed.com. Accessed 13 Mar 2018.

"respiro." A Latin Dictionary. 1879. Ed. Charlton T. Lewis and Charles Short. Oxford: Clarendon Press. Online Version. www.perseus.tufts.edu/hopper/ text?doc=Perseus\%3Atext\%3A1999.04.0059\%3Aentry\%3Drespiro. Accessed 13 Mar 2018.

Witmer, Robert. 2003. Blow. In The New Grove Dictionary of Jazz, ed. Barry Kernfeld. Grove Music Online, Oxford Music Online: Oxford University Press. http://www.oxfordmusiconline.com. Accessed 13 Mar 2018. 
Open Access This chapter is licensed under the terms of the Creative Commons Attribution 4.0 International License (http://creativecommons.org/licenses/ by $/ 4.0 /$ ), which permits use, sharing, adaptation, distribution and reproduction in any medium or format, as long as you give appropriate credit to the original author(s) and the source, provide a link to the Creative Commons license and indicate if changes were made.

The images or other third party material in this chapter are included in the chapter's Creative Commons license, unless indicated otherwise in a credit line to the material. If material is not included in the chapter's Creative Commons license and your intended use is not permitted by statutory regulation or exceeds the permitted use, you will need to obtain permission directly from the copyright holder.

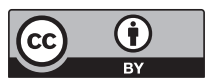

